\title{
PLEISTOCENE PLANTS FROM ZARZAL FORMATION, MIDDLE VALLEY OF THE CAUCA RIVER BASIN, COLOMBIA
}

\author{
MARIA ALEJANDRA ROJAS-GRANADA $\mathbb{D}$, ARNOL CARDOZO-RUEDA (D, \\ CARLOS ALBERTO AGUDELO HENAO (D \\ Programa de Biología, Ciencias Básicas y Tecnologías, Universidad del Quindío, \\ Av. 15 Calle 12 Norte, Armenia-Quindío, Colombia. \\ alejarojas199623@gmail.com,arnolcardozo98@gmail.com,agudelohenao@yahoo.com
}

\author{
JULIANA GUZMÁN (D \\ Laboratório de Micropaleontologia Aplicada (LAGESE/LITPEG), Departamento de Geologia, \\ Universidade Federal de Pernambuco, Av. da Arquitetura, 50740-540 Recife, PE, Brazil. \\ julitaguzmang@gmail.com
}

PAULA ANDREA SUCERQUIA RENDON (D)

Programa de Pós-Graduação em Geociências, Universidade Federal de Pernambuco, Av. da Arquitetura, s/n, 50740-550, Recife, PE, Brazil.

psucerquia@gmail.com

\begin{abstract}
We report macro and meso palaeobotanical records from the Zarzal Formation, in the Cauca River Depression, and the QuindíoRisaralda Basin between the Western and the Central Cordilleras of Colombia. The fossils correspond to leaves and seeds obtained from layers of mudstones, diatomites, and tuffaceous sandstones deposited in the inter-Andean valleys of Cauca and La Vieja rivers, separated by the Serranía Santa Bárbara ridge between the Valle del Cauca and Quindío departments. The sediments of the Pleistocene Zarzal Formation were deposited in a fluvial-lacustrine environment, with volcanic influence originated in the Central Cordillera to the east of the depositional area. The study here presented allowed the identification of thirteen morphotypes of leaf impressions grouped in six Angiosperm families: Poaceae?/Cyperaceae? and Araceae of the Monocots group, Melastomataceae, Fabaceae and Lauraceae belonging to the Eudicots group and one family of Lycopsida: Thelypteridaceae. On the other hand, very well-preserved silicified micro-seeds were grouped in eight morphotypes, belonging to the botanical groups Cyperaceae and Asteraceae. The fossils found allowed us to identify two types of plant associations that exhibit paleofloristic richness. In the Cauca River Basin, an autochthonous to parautocthonous plant association could correspond to a subAndean gallery forest, whilst in the La Vieja River Basin a parautocthonous plant association indicates a swamped floodplain.
\end{abstract}

Keywords: paleoflora, leaves, seeds, Cauca River, La Vieja River, lacustrine deposit.

RESUMO - Neste trabalho reportamos os primeiros registros macro e mesofitofósseis da Formação Zarzal, na Depressão do Rio Cauca e na Bacia Quindío-Risaralda entre as Cordilheiras Ocidental e Central da Colômbia. Os fósseis correspondem a folhas e sementes obtidas de estratos de lamito, diatomito e arenitos tufáceos, depositados nos vales interandinos dos rios Cauca e La Vieja, separados pela Serranía Santa Barbara, entre os departamentos do Valle del Cauca e Quindío. Os sedimentos da Formação Zarzal, de idade pleistocênica, foram depositados em um ambiente flúvio-lacustre, com influência vulcânica originada na Cordilheira Central a leste da área deposicional. O estudo apresentado aqui, permitiu a identificação de treze morfotipos de impressões foliares agrupados em seis famílias de Angiosperma: Poaceae?/ Cyperaceae? e Araceae do grupo de monocotiledônea, Melastomataceae, Fabaceae e Lauraceae, pertencentes ao grupo de eudicotiledônea e uma família de Lycopsida: Thelypteridaceae. Por outra parte, sementes silicificadas muito bem preservadas foram agrupadas em oito morfotipos, pertencentes aos grupos botânicos Cyperaceae e Asteraceae. Os fósseis encontrados nos permitiram identificar dois tipos de associações vegetais que exibem riqueza paleoflorística. Na Bacia do Rio Cauca, uma associação vegetal autóctone a parautóctone poderia corresponder a uma floresta de galeria sub-andina, enquanto na Bacia do Rio La Vieja uma associação vegetal parautóctone indica uma planície de inundação pantanosa.

Palavras-chave: paleoflora, folhas, sementes, Rio Cauca, Rio La Vieja, depósito lacustre. 


\section{INTRODUCTION}

In the intermountain valleys of the Cauca and La Vieja rivers (central Andes of Colombia) sedimentary rocks of the Zarzal Formation (ZF) outcrop (Van Der Hammen \& Hooghiemstra, 1997) (Figure 1). A set of fluvial-lacustrine and volcanic rocks with layers of diatomites, mudstones, claystones, and tuffaceous sandstones characterize this unit (Jaramillo et al., 2017). Studies of Cenozoic fossil plants in the region of the middle valley of the Cauca River Basin are restricted to palynology of several units including Zarzal Formation (e.g. Van Der Hammen, 1958; Van Der Hammen \& Hooghiemstra, 1997; Moreno-Sanchez, 2008; Suter et al., 2008; Bedoya \& Giraldo, 2009; Neuwerth, 2012) and macrofossils from Miocene La Paila and La Pobreza Formations (Bedoya \& Giraldo, 2009; Sanín et al., 2016) and Pliocene Mesa Formation (Botero, 2015). Nevertheless, despite the abundant angiosperm fossils content of the correlative Miocene La Paila and La Pobreza formations, only the Thelypteris subg. Meniscium Reed, 1968 fern leaves had its taxonomy studied in detail (Sanín et al., 2016). Near the President landfill, San Pedro Municipality (Valle del Cauca), López et al., (2009) mentioned the presence of plant macrofossils in the area mapped by the Geological Service of Colombia (SGC) as La Paila Formation, and due to the diatom-bearing rocks associated, the authors considered the deposits of this area corresponding to the Zarzal Formation and not to La Paila Formation, but no paleontological study has been published of these fossil findings. Notwithstanding, the Zarzal Formation is well known in this region by its diatom content. A detailed paleolimnological study characterizing and dating the paleolake implanted in the Cauca Basin during the Zarzal Formation deposition, was carried out by Jaramillo et al. (2017), determining the taxonomy of diatom algae, and radiometric ages for tuffaceous sandstones. New fossil plant evidence is here reported for the Zarzal Formation, and the presence not only of well-preserved leaf imprints, but also seeds, will allow identifying the botanical groups that existed there. The objective of this study is to identify the fossil plant assemblages from Pleistocene lacustrine deposits of the Cauca and La Vieja valleys (Valle del Cauca and Quindío departments, Colombia). The results presented here constitute the first systematic classification of the fossil plant assemblages of the Zarzal Formation, through a descriptive systematic paleobotany, which help understanding some paleoecological relationships.

\section{GEOLOGY AND SEDIMENTOLOGICAL CONTEXT}

The fossiliferous formation studied herein was named by Van Der Hammen (1958) as the Zarzal Formation. This geological unit is located in the middle valley of the Cauca Basin, outcropping on both sides of the Serranía Santa Barbara mountain range (SSB), east of Quindío Department $(\mathbf{Q})$, and West of Valle del Cauca Department (VC). The basin is an intermountain depression in the northern Andes, with a complex tectonic evolution influenced by the interaction of the Nazca, Caribbean, and South American plates. The Cauca River Basin is structurally positioned on the Romeral Fault System that marks the limit between the continental basement to the east and the Cretaceous oceanic terrains accreted to the continent, to the west (Suter et al., 2008).

With a thickness of approximately $30 \mathrm{~m}$, the Zarzal Formation is mainly composed of intercalated layers of diatomites, claystones, tuffaceous sandstones, and mudstones of fluvial to lacustrine environment affected by volcanic ash fall and volcaniclastic mass flows (Suter et al., 2008; Jaramillo et al., 2017). Thus, the deposition of the Zarzal Formation is the result of a complex interaction of a fluvial system with the dynamical conditions of the Quindío-Risaralda Fan and the East Cartago and North Cartago fans, which dammed the La Vieja River in an older stage and later the Cauca River, producing at least two lacustrine intervals (Suter et al., 2008). Palynological investigations have shown the presence of Alnus pollen in clays of the Zarzal Formation (Neuwerth et al., 2006; and preliminary results linked to our study). Because the first record of the Alnus tree in Colombia dates back to less than 1 Ma (Hooghiemstra \& Cleef, 1995), a large part of the Zarzal Formation can be interpreted as being of Pleistocene age (Suter et al., 2008). From an ash fall deposit, Jaramillo et al. (2017) performed radiometric analyzes of $\mathrm{U}-\mathrm{Th} / \mathrm{He}$ in apatite and zircon grains, most of these displaying consistent ages between 0.20 and 0.60 Ma with a weighted mean of $0.53 \pm 0.12$ Ma (Chibanian, Middle Pleistocene). Two multigrain aliquots yielded identical age of $\sim 2 \mathrm{Ma}$ (Gelasian, Early Pleistocene) which according to the mentioned authors could represent a mixture of ash fall-out of the Chibanian volcanic event plus the contribution of some grains from a previous Gelasian event.

\section{MATERIAL AND METHODS}

\section{Field trips}

Three field trips were made to the West of SSB-Valle del Río Cauca (Holguin, Valle del Cauca) and the East of SSBValle del Río La Vieja (Veraguas, Montenegro, Quindío). The fossil material was collected in both localities, always trying to extract large blocks to recover the specimens as complete as possible. Geological annotations of the fossiliferous localities were performed to make the stratigraphic sections. One of the localities here studied is located near La Montaña del Ocaso nature reserve and the Veraguas farm $\left(4^{\circ} 34^{\prime} 08^{\prime \prime} \mathrm{N}, 75^{\circ} 51^{\prime} 03^{\prime \prime}\right.$ W) in La Vieja River valley, Montenegro-Q, to the west of the SSB. The other locality corresponds to the Holguín Village $\left(4^{\circ} 31^{\prime} 17^{\prime \prime} \mathrm{N}, 76^{\circ} 0^{\prime} 22^{\prime \prime} \mathrm{W}\right)$ in the middle valley of the Cauca River, to the east of the SSB (Figures 1 and 2).

The stratigraphic sections from which the samples were extracted, were obtained from the Veraguas farm and near Holguín Village (Figure 3). A description of the stratigraphic sections is presented below:

Section A. W de SSB-Cauca River valley (Holguín, Valle del Cauca). This stratigraphic section is approximately 3 $\mathrm{m}$ high. This section is characterized by: (1) fine-grained mudstones with galleries of insects; (2) intercalation of 

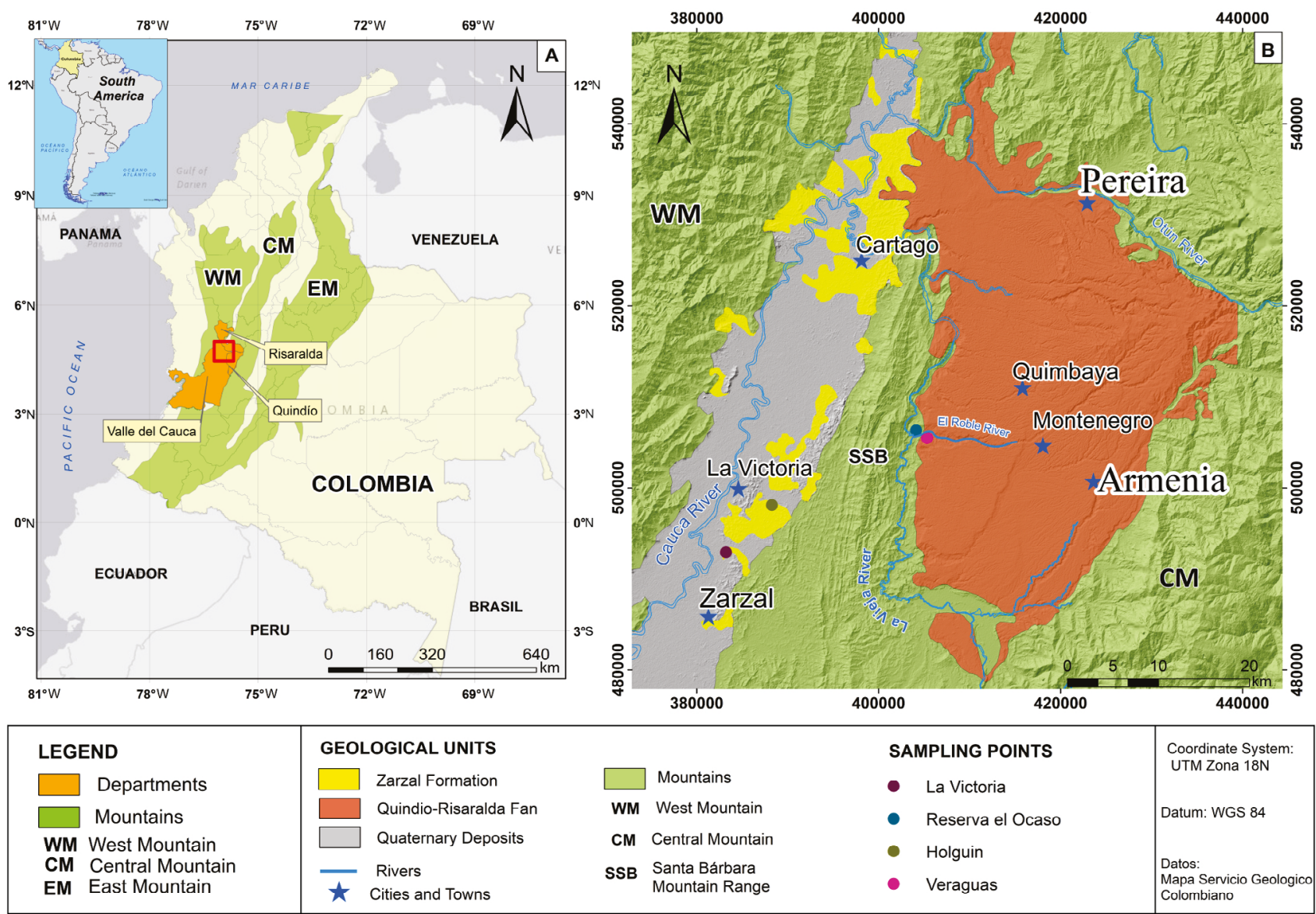

Figure 1. Location maps. A, map of Colombia with the studied departments and mountain ranges (WC, CC, and EC). B, geologic map showing the sampling sites, Quindío-Risaralda fan and Quaternary deposits in the area after Jaramillo et al. (2017). Metadata acquired from the online Colombian Geological Service - SGC.

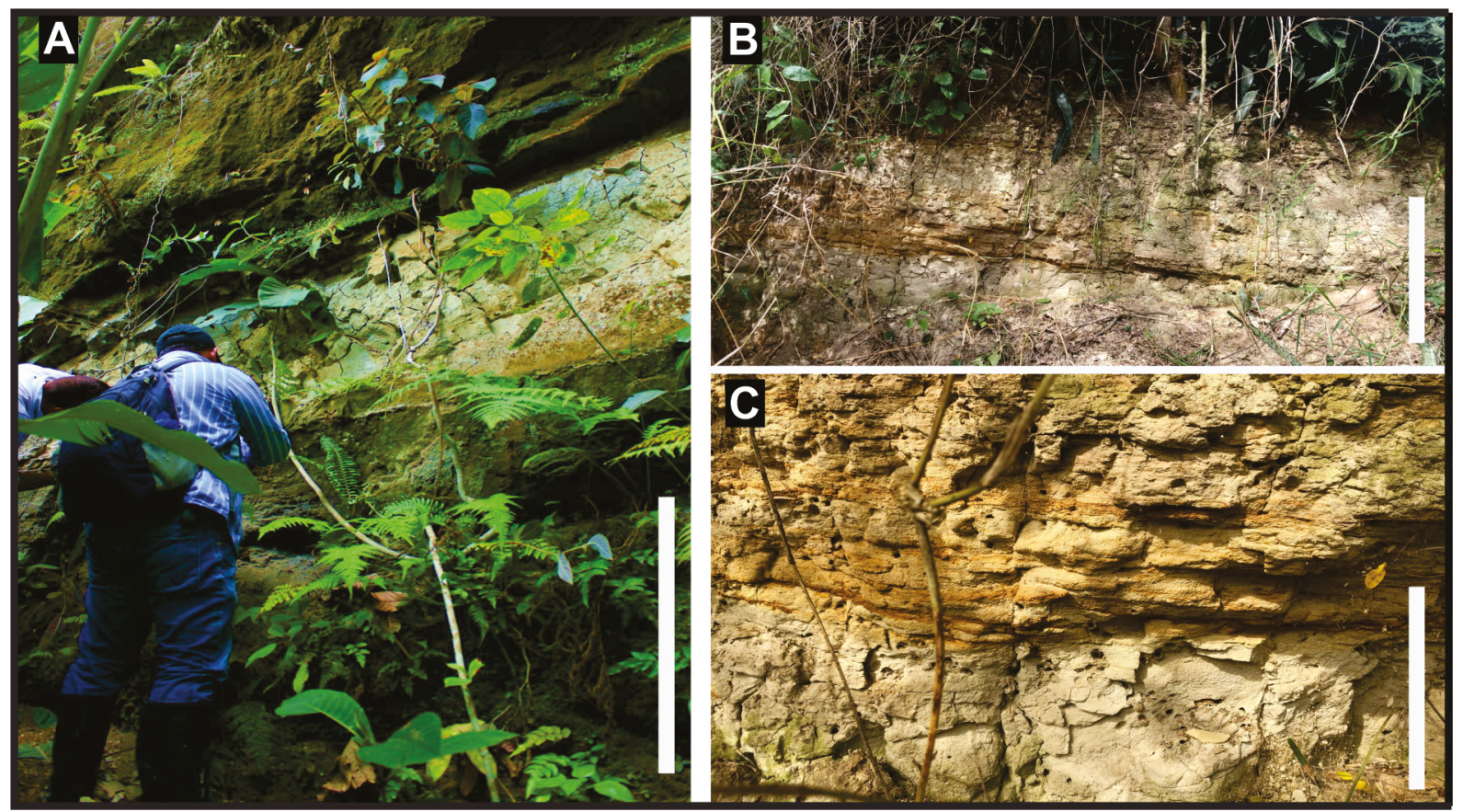

Figure 2. Outcrop photographs. A, the Veraguas farm (Montenegro-Q); B-C, Holguín Village (La Victoria, Valle del Cauca). Scale bars $=1 \mathrm{~m}$. 

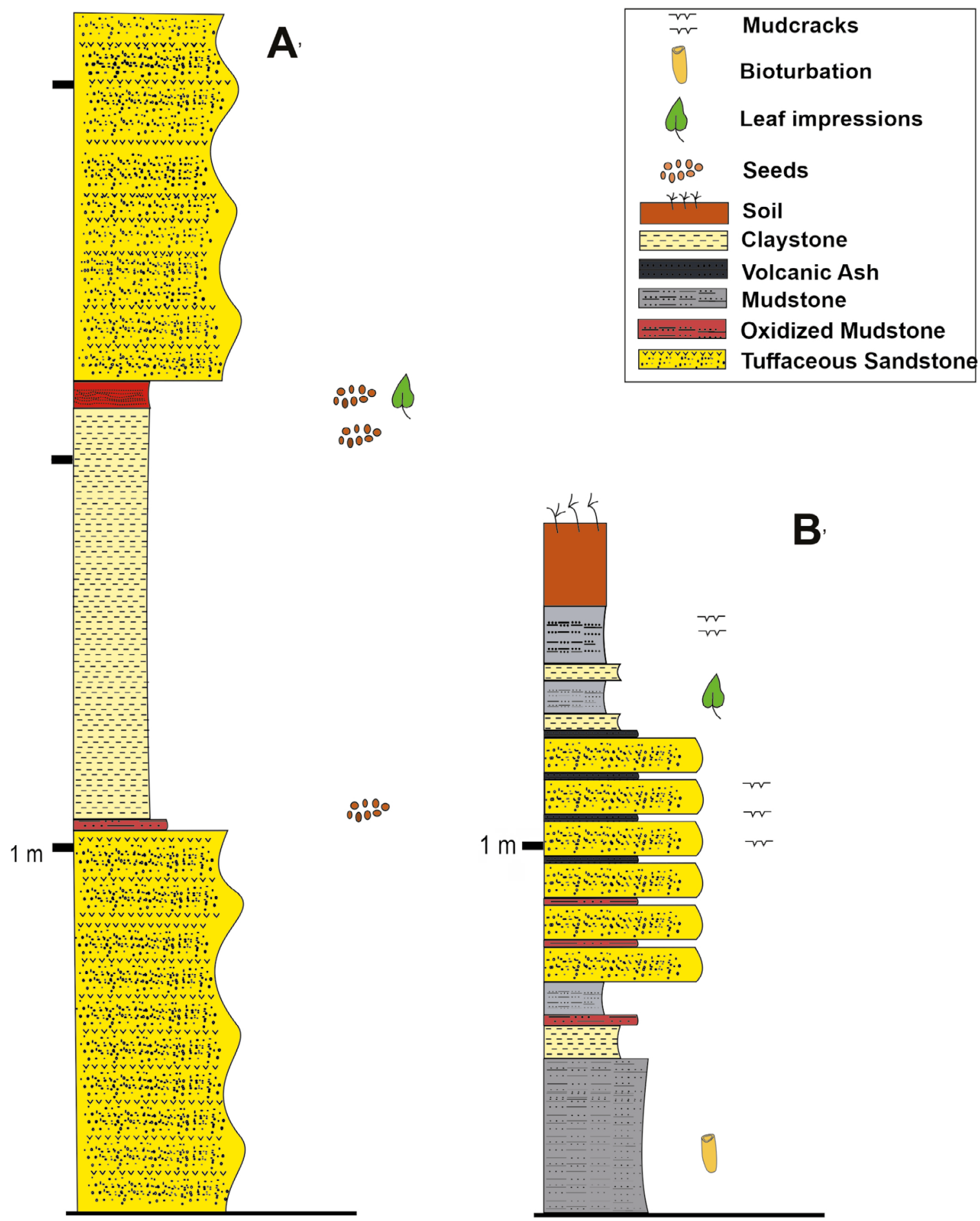

Figure 3. Lithostratigraphic columns: A, Veraguas, Montenegro-Q; B, Holguín, La Victoria-VC.

claystone and mudstone with the presence of leaves and an oxidized level; (3) medium-grained sandstone with intercalations of oxidized levels. Moderate bioturbation; (4) medium-grained sandstone with ash and desiccation marks; (5) intercalation of claystone and siltstone with the presence of leaves; (6) arcillolite, with desiccation cracks; (7) soil horizon-type A (Figure 3A).
Section B. E de SSB-La Vieja River valley (Veraguas, Montenegro). This stratigraphic section is approximately 3.5 $\mathrm{m}$ high. It has: (1) medium to coarse-grained sandstone with ash; (2) Fe oxide level and mudstone; (3) fine bioturbated claystone, with seed fossils, recent roots, and fragments of insect fossils, presence of diatoms, and charcoal; (4) mediumgrained tuffaceous sandstone (Figure 3B). 


\section{Fossil leaves sampling, treatment, and methods}

A hundred leaf impressions were collected, most of them were confirmed to have an affinity to Eudicot angiosperms, some monocots, and one specimen of Pteridophyta. Eighty-six leaf specimens studied here were collected from the Holguín Village W of SSB, and fourteen were obtained from Veraguas farm E of SSB.

The fossils were deposited in the Herbarium at Facultad de Ciencias Básicas y Tecnologías, Universidad del Quindío (HUQ). For transportation, the specimens were wrapped in tissue paper, and newspaper, and were packed in plastic bags, to avoid damage. In the laboratory, the specimens were carefully unwrapped, and classified according to the outcrop, then placed in drawers and labeled.

The samples were prepared by removing the matrix to expose the complete plant remains, carefully using chisels of various sizes and shapes and a small hammer, with the sample placed over a small bag filled with sand.

The morphotypes were designated by a number and a six-letter prefix that correspond to the Herbarium of the Universidad del Quindío, with its respective collection of Rocks, Minerals and Fossils (HUQ-RMF) under the numbers 1-100. The rock fragments that did not present macro-fossils were prepared following a seed methodology.

For the analysis of the foliar architecture, the specimens were photographed and observed through a Carl Zeiss arm stereoscope. Each morphotype was described following the terminology of the Manual of the Leaf Architecture (Ellis et al., 2009). The fossils were photographed with a Nikon D3100 camera and Corel Draw ${ }^{\circledR}$ was used for the image processing. Taxonomic identification was made using botanical literature.

\section{Seeds recovery and identification}

Aiming the recovery of calcareous and silicified microfossils, approximately $60-70 \mathrm{~g}$ of rock fragments were crushed and consecutively placed in beakers to react with hydrogen peroxide $\left(\mathrm{H}_{2} \mathrm{O}_{2}\right)$ for $24 \mathrm{~h}$, subsequently the samples were washed and sieved through a $45 \mu \mathrm{m}$ mesh, and later placed in the oven to be dried at $70^{\circ} \mathrm{C}$ for $24 \mathrm{~h}$. The dry samples were sieved a second time, through 500, 250, 150 and $60 \mu \mathrm{m}$ meshes. The material retained in each mesh was observed under Zeiss stereoscopy and microseeds were picked-up and stored in a micropaleontology slide which was deposited in the Herbarium at Facultad de Ciencias Básicas y Tecnologías, Universidad del Quindío, in the respective collection of Rocks, Minerals and Fossils (HUQ-RMF) under the number 101.

Selected seed specimens were pin-mounted (stub) to obtain the scanning electron microscope (SEM) photographs at the Laboratório de Micropaleontologia Aplicada Universidade Federal de Pernambuco, Brazil. Size and surface characteristics were analyzed following Pérez-Cortéz et al. (2014). Terminology and morphological characters were adopted from Larridon et al. (2011), Martinetto et al. (2014), Shalabi \& Gazer (2015), Hussein \& Eldemerdash (2017) and Ghimire et al. (2018).

\section{SYSTEMATIC PALEOBOTANY}

\section{Leaves}

\section{POLYPODIOPSIDA GROUP}

Characteristics. Secondary veins end at the margin of the leaf blade. Tertiary veins of chevron shape, where it does not anastomose with the following chevron.

\section{M1 morphotype \\ (Figure 4A-A')}

Morphotype example. HUQ-RMF $38 \mathrm{~b}$.

Material. HUQ-RMF 38a, 38b, 38c.

Description. Incomplete specimen of a pinnate frond of a fern; the impression of the right side of the pinna is observed. Size $4 \mathrm{~cm}$ long and $1.5 \mathrm{~cm}$ wide. Entire margin to sinuous or serrated. Undifferentiated primary venation. Secondary veins oblique in relation to the middle vein and slightly arched, with a divergence angle of $28^{\circ}$, the uniform spacing of $0.3 \mathrm{~mm}$, also, the secondary veins end at the margin of the leaf blade. Tertiary veins of chevron shape with an edge of $0.02 \mathrm{~mm}$, where it does not anastomose with the following chevron. Chevrons 14 to 15 .

Discussion. Three specimens of this morphotype were identified, despite being relatively rare they are distinguished by their tertiary vein pattern and chevron formation. All specimens have a well-preserved shape. The specimen is closely related to the family Thelypteridaceae (Pichi-Sermolli, 1970), which in its foliar architecture is characterized by meniscioid venation (Smith, 1990), it also has a polygonal areole. Sanin et al. (2016) report fossil impressions of Thelypteris subg. Meniscium Reed, 1968 in Miocene deposits of La Paila and La Pobreza formations, Cauca Basin. The description of the vein reticulation these fossil leaves is described as meniscioid, because of the polygonal areoles that enclose a single free-ending veinlet subsidiary to the sori (after the subgenus Meniscium) (Smith \& Cranfill, 2002). Meniscioid venation is found in two Neotropical subgenera of Thelypteris: subg. Meniscium and subg. Goniopteris Presl, 1836 (Smith \& Cranfill, 2002).

Systematic affinity. The occurrence of more than ten areolae between the costa and the margin which is sinuate to serrate pinnae in our specimens led to identify it as Thelypteris subg. Meniscium and not Thelypteris subg. Goniopteris.

Geographic occurrence. Holguin Village, La Victoria Municipality, Cauca Valley.

Age. Chibanian, Pleistocene.

Stratigraphic occurrence. The most ancient fossil records of Thelypteris subg. Meniscium come from the Eocene of England and Ireland (Collinson, 2001). At present-day more than fifteen extant species of this subgenus are identified.

\section{ANGIOSPERM GROUP 1}

Characteristics. Main venation parallel, of two or more size classes, the veins joining successively from the outside 
at the apex and forming a fimbrial vein, transverse veinlets, unbranched (leaf blade characters: level), veinlet endings not free, margins, broad base.

$$
\begin{aligned}
& \text { M2 morphotype } \\
& \text { (Figure 4B-B') }
\end{aligned}
$$

Morphotype example. HUQ-RMF 70.

Material. HUQ-RMF 70, 77.

Description. Incomplete leaf impression. Size $10 \mathrm{~cm}$ long and $17 \mathrm{~cm}$ wide. Base and apex not preserved. Entire margin. Massive straight primary vein. Main venation parallel.

Discussion. Two well-preserved specimens of this morphotype were distinguished by usually oblong or linear parallelinervias, sheathing at the base; petiole very poorly developed and without stipules. The specimens are closely related to the class Liliopsida, which in its foliar architecture is characterized by nerves parallel or pinnate-parallel, sometimes reticulated (Welsh et al., 1987). Furthermore, Batsch (1802) described the class Liliopsida differentiating it from the group of magnolids by its characteristic parallelinervia foliar architecture among other characteristics.

Systematic affinity. Liliopsida Batsch, 1802.

Geographic occurrence. Veraguas farm, Montenegro Municipality, La Vieja River Valley.

Age. Pleistocene.

Stratigraphic occurrence. Class Liliopsida ranges from Jurassic (Savard et al., 1994) to Recent.

\section{ANGIOSPERM GROUP 2}

Characteristics. Main venation reticulated (pinnate or webbed), of two or more size classes pinnate primary vein, smooth and with a weakly curved course. Secondary veins, alternate and veins up to fifth degree.

\section{M3 morphotype}

(Figure 4C-C')

Morphotype example. HUQ-RMF 23.

Material. HUQ-RMF 2, 5, 8, 13, 15, 23, 28, 35, 37, 39, 55, $59,64,79$.

Description. Incomplete leaf impressions. Size $5.5 \mathrm{~cm}$ long and $1.9 \mathrm{~cm}$ wide. Shape elliptic closely subclass. Symmetric. Acuminate apex. Base not preserved. Petiole probably marginal. Entire and smooth margin. Pinnate primary vein, smooth and with a weakly curved course. Eucamptodromous secondary veins, alternate, $1.1 \mathrm{~cm}$ long, with a distance between them of $0.5 \mathrm{~mm}$ to $1.12 \mathrm{~cm}$, other orders of veins are difficult to distinguish. Putative herbivorous markings are observed on the apex.

Discussion. Fourteen specimens of this morphotype were identified, they are distinguished because their leaves have mainly reticulated veins and their leaves are often compound. All specimens have a well-preserved shape. The specimens are closely related to the class Magnoliopsida, which in its foliar architecture is characterized by nerves reticulated and veins up to fifth degree (Welsh et al., 1987). Brongn (1843) described the class Magnoliopsida differentiating its foliar architecture in venation typically reticulate, either pinnate or palmate and mostly not closed (with free vein-endings).

Systematic affinity. Magnoliopsida Brongn, 1843.

Geographic occurrence. Holguin Village, La Victoria municipality, Cauca River Valley.

Age. Chibanian, Pleistocene.

Stratigraphic occurrence. Class Magnoliopsida ranges from Cretaceous (Soltis \& Soltis, 2004) to Recent.

\section{ANGIOSPERM GROUP 3}

Characteristics. Pinnate venation. Massive straight primary vein. Secondary veins eucamptodromous with divergence angle, therefore, moderately acute, with a distance between the secondary veins, being slightly wider towards the base.

M4 morphotype

(Figure 4D-D')

Morphotype example. HUQ-RMF 19.

Material. HUQ-RMF 1, 19a, 19b, 27, 29, 41, 45, 49, and 60. Description. Complete leaf impression specimen. Size 7.5 $\mathrm{cm}$ long and $5 \mathrm{~cm}$ wide. Oblong shape. Base and apex not preserved. Symmetrical blade. Pulvinate petiole. Pinnate venation. Massive straight primary vein. Secondary veins eucamptodromous with divergence angle between $42^{\circ}$ to $45^{\circ}$, therefore, moderately acute, uniform along the length of the leaf, with a length of $1.5 \mathrm{~cm}$ at the apex and $1.1 \mathrm{~cm}$ from the base, with a distance between the secondary veins of $1-1.5 \mathrm{~cm}$, being slightly wider towards the base. Simple intersection veins. Pairs of secondary veins (between four to six pairs). Percurrent tertiary veins, simple. Quaternary veins are probably reticulated.

Discussion. Eight specimens of this morphotype were identified, they are distinguished because their leaves have mainly reticulated veins and the secondary vein, in the proximal is perpendicular to the secondary vein (Welsh, 1987). The specimens are closely related to the family Lauraceae Jussieu, 1789, which is characterized by leaves presenting a pattern of pinnate venation with only one primary vein. The secondary pattern in general is brochidodrome, with occurrence of mixture with eucamptodrome type. The angle of divergence is exclusively acute $\left(60-70^{\circ}\right)$ in relation to the primary rib (Gomes-Bezerra et al., 2011). In addition, our morphotype presents characters from the genus Nectandra Rotboll, 1778. This genus presents a marked arc of the secondary veins in an acropetic direction from the base of the lamina, forming the characteristic eucalyptus pattern and a low number of secondary pair veins (between four and six pairs). Systematic affinity. Nectandra sp. 1.

Geographic occurrence. Holguin Village, La Victoria municipality, Cauca River Valley.

Age. Chibanian, Pleistocene.

Stratigraphic occurrence. Genus Nectandra ranges from Paleogene (Trofimov et al., 2016) to Recent. 

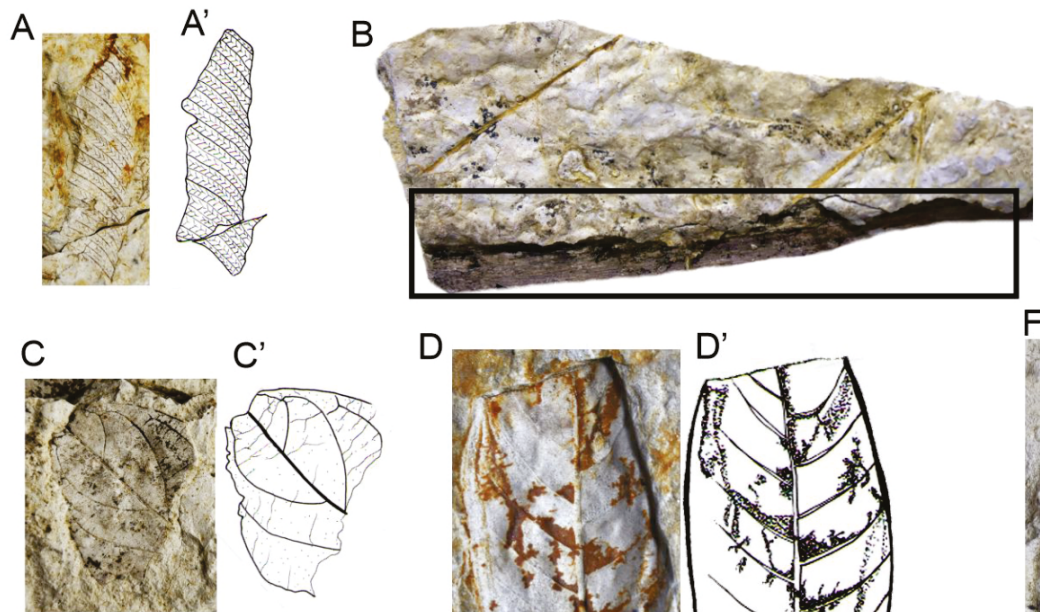

$\mathrm{B}^{\prime}$
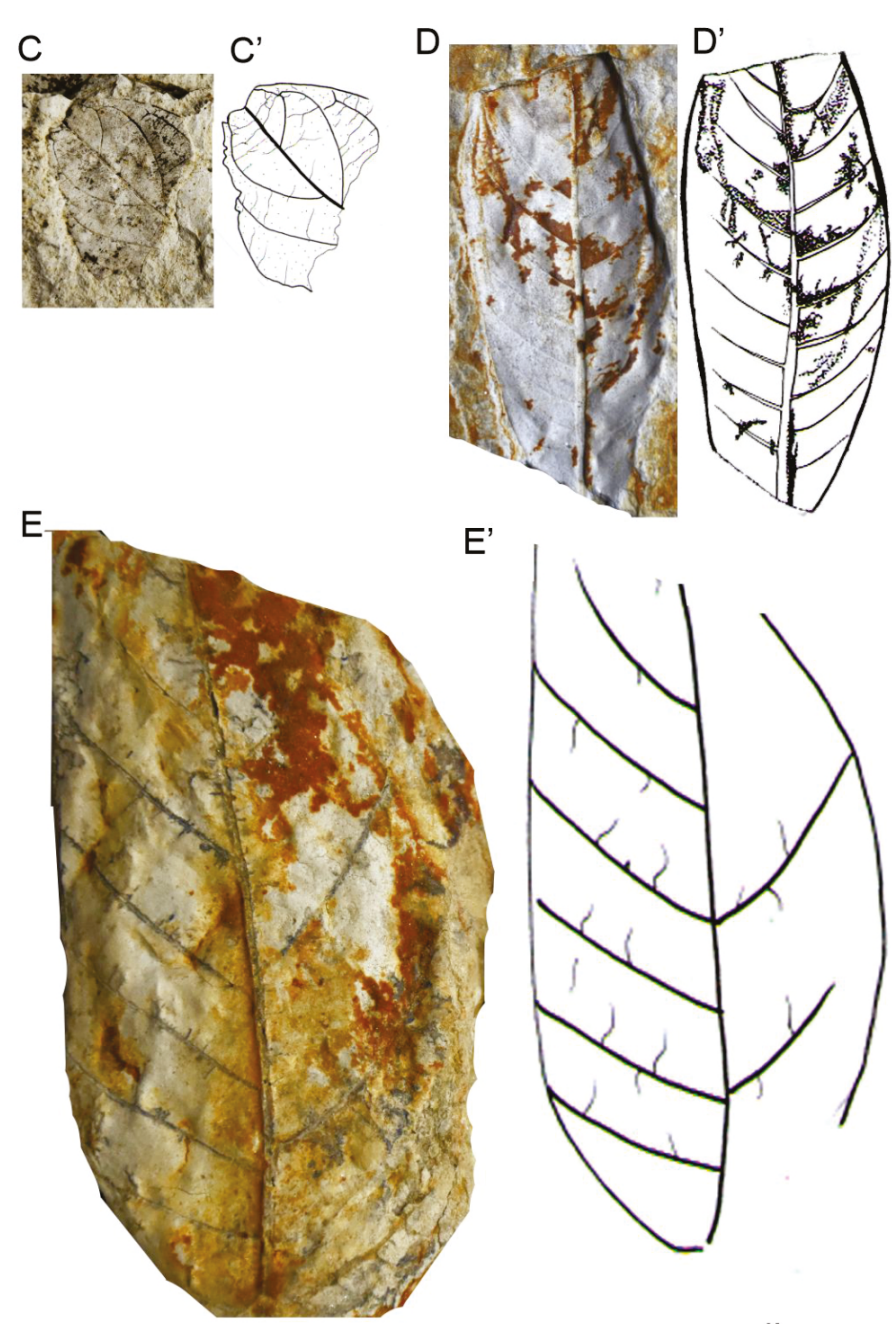

E'

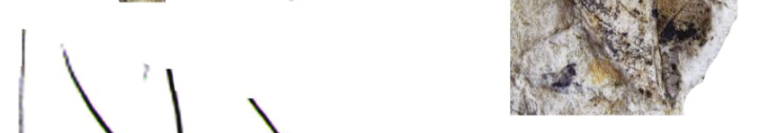

$\mathrm{F}$

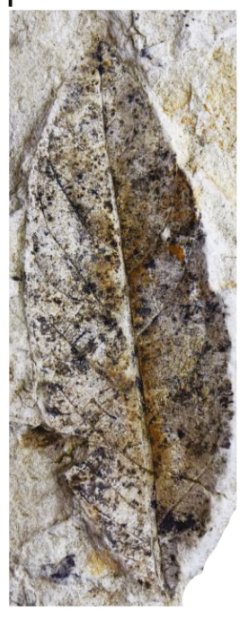

G
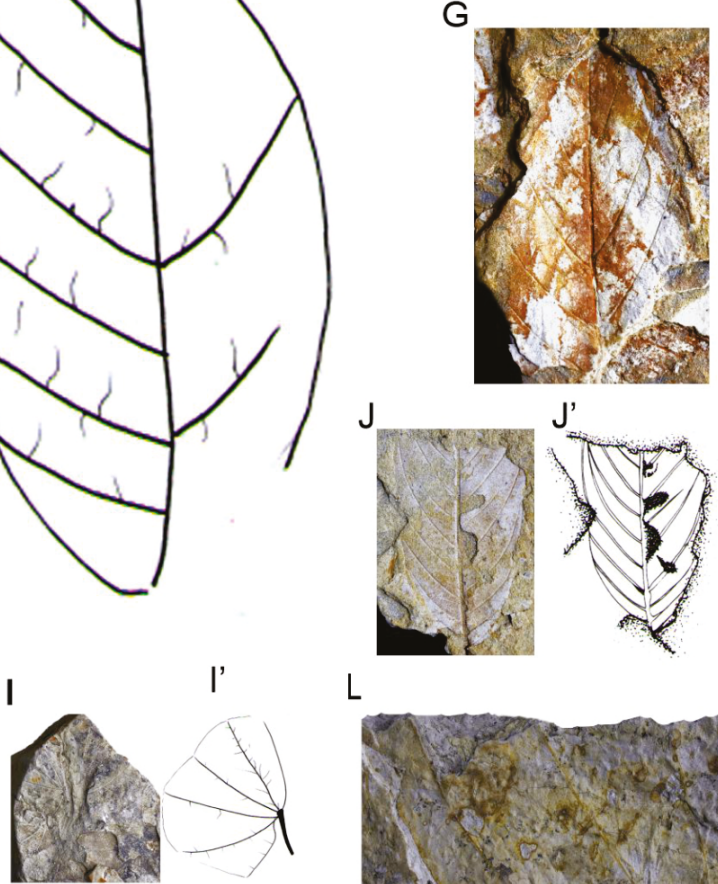

L

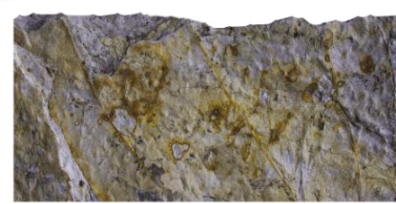

M

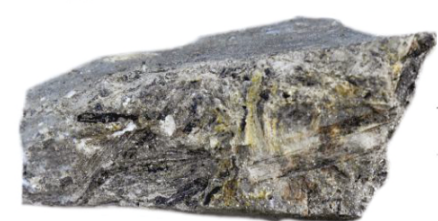

$F^{\prime}$

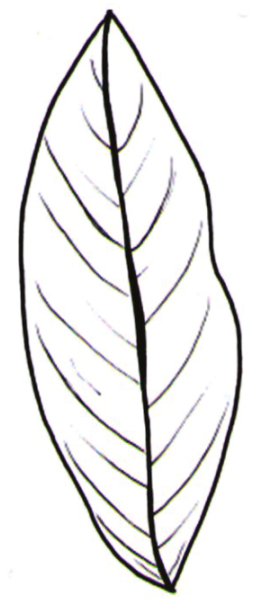

$\mathrm{G}^{\prime}$
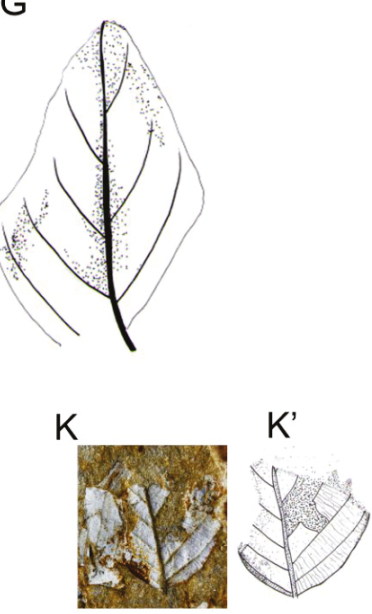

L'

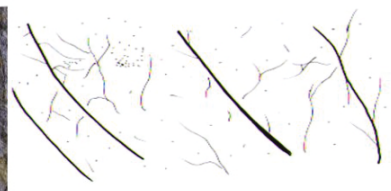

$M^{\prime}$

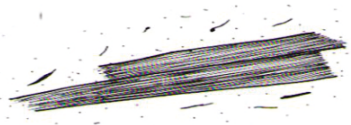

Figure 4. Fossil leaves and their respective illustrations with affinities to Family Thelypteridaceae: (A-A') Thelypteris. Class Liliopsida (B-B'). Class Magnoliopsida (C-C'). Nectandra sp. 1 (D-D'). Nectandra sp. 2 (E-E'). Ocotea sp. (F-F'). Family Lauraceae (G-G'). Family Fabaceae Calliandra sp. (H-H'). Bauhinia sp. (I-I'). Inga sp. (J-J'). Family Melastomataceae: Miconia?/Clidemia? (K-K'). Family Asteraceae (L). Family Poaceae? or Cyperaceae? (M). The impressions have their respective reconstruction on the right side with letter (A', B', etc.). Scale bar $=2 \mathrm{~cm}$. 
M5 morphotype

(Figure 4E-E')

Morphotype example. HUQ-RMF 61.

Material. HUQ-RMF 61.

Description. Incomplete leaf impression. Size $13 \mathrm{~cm}$ long and $6.2 \mathrm{~cm}$ wide. Shape elliptical and symmetrical. Base and apex not preserved. Entire margin. Pinnate venation. Massive and slightly curved primary vein in the center of the lamina. Secondary veins brochidodromous, uniformly curved and alternate; with an angle of divergence of $35^{\circ}$, therefore, moderately acute, with length of $4-5 \mathrm{~cm}$, distance between veins of $1-1.5 \mathrm{~cm}$, increasing towards the apex of $2-2.5 ; 5-6$ secondary pairs veins. Intersecondary compound veins, $1.5 \mathrm{~cm}$ long. Tertiary veins of two types, curved to the secondary vein, in the proximal region and perpendicular to the secondary vein in the distal region, and those that connect two secondary veins are percurrent, straight and sinuous.

Discussion. One specimen that was identified sharing some of the previous described characteristics of Nectandra sp. 1. However, it is identified as another morphotype due to the difference in its secondary vein and the presence of an epidemic tertiary percurrent veins.

Systematic affinity. Nectandra sp. 2.

Geographic occurrence. Holguin Village, La Victoria Municipality, Cauca River Valley.

Age. Chibanian, Pleistocene.

\section{M6 morphotype}

(Figure 4F-F')

Morphotype example. HUQ-RMF 20.

Material. HUQ-RMF 20a, 20b.

Description. Complete specimen of leaf impression with part and counterpart, $9 \mathrm{~cm}$ long and $3.5 \mathrm{~cm}$ wide. Form elliptical, symmetrical. Acute apex and complex base. Marginal petiole position. Entire margin. Pinnate venation. Weak middle vein with a straight course. Secondary vein eucamptodromous, with dichotomous branches that arise in the middle of the leaf blade and are arched; with divergence angle between $35^{\circ}$ to $45^{\circ}$, therefore, moderate acute, uniform throughout the blade, with a length of 2.0 to $1.5 \mathrm{~cm}$ at the apex and 2.0 to $2.5 \mathrm{~cm}$ from the base, with a distance between the secondary veins of $1.0 \mathrm{~cm}$ and 5 pairs of secondary veins. A secondary vein is observed throughout the lamina, which is contacting the primary vein runs parallel through it with $0.1 \mathrm{~cm}$. Simple intersection veins. Percurrent tertiary vein, straight course, with a probably alternate organization and straight course. Thin quaternary vein with an orthogonal course. Presence of quadrangular and rectangular areolas. Venules one time branched.

Discussion. One specimen was identified sharing the previous described characteristics of the family Lauraceae. Nectandra is a similar genus to Ocotea Aublet, 1775, these are closely related. The most characteristic features to distinguish between them are the position of the locules in the anther (in an arch in Nectandra and in two rows in Ocotea). However, in foliar architecture the genus Ocotea is characterized by the shape of the leaves that is ovate to obovate, in addition the base of the blade can become obtuse-truncated, there are a higher density of secondary veins (between eight to ten pairs), a faint brochidodromal to craspedodromal pattern (Welsh et al., 1987), and one more arc of secondary veins pronounced towards the apical zone of the lamina.

Systematic affinity. Ocotea sp.

Geographic occurrence. Holguin Village, La Victoria Municipality, Cauca River Valley.

Age. Chibanian, Pleistocene.

Stratigraphic occurrence. The genus Ocotea ranges from Neogene to Recent (Van der Werff, 2002).

M7 morphotype

(Figure 4G-G')

Morphotype example. HUQ-RMF 25.

Material. HUQ-RMF 4, 25, 26, 47, 53, 54, 56, 58, 62.

Description. Incomplete leaf impressions, $6 \mathrm{~cm}$ long and 3 $\mathrm{cm}$ wide. Elliptical, symmetrical shape. Base and apex not preserved. Marginal petiole position and petiole probably widened. Entire margin. Pinnate primary vein. Massive middle vein and straight course. Eucamtodromous secondary veins, with lengths of 3 in the apical ones and 2 to 2.4 in the basal ones, with a distance between basal veins of $0.9 \mathrm{~mm}$ and divergence angles of $38^{\circ}$, while the apical ones are reduced to $0.3 \mathrm{~mm}$ and with divergence angles of $40^{\circ}$. Presence of a pair of intersectoral veins in the lamina area, with an oscillation of 0.5 to $1.3 \mathrm{~cm}$. Also, a pair of basal marginal veins are seen. In the basal portion, a secondary vein is observed when is contacting the primary vein runs parallel with $0.3 \mathrm{~mm}$. Have epidemial tertiary percurrent veins.

Discussion. Nine specimens of this morphotype were identified, the characteristics could correspond to those mentioned above in the Lauraceae family; however, due to the fragmentation of the sample, it is not possible to identify it with greater accuracy. It is identified as another morphotype due to the difference in the basal part of the secondary vein, since, when the secondary vein is in contact with the primary vein, it runs a few mm parallel until it reaches the base, they do not join.

Systematic affinity. Lauraceae.

Geographic occurrence. Holguin Village, La Victoria municipality, Cauca River Valley.

Age. Chibanian, Pleistocene.

Stratigraphic occurrence. The family Lauraceae ranges from Jurassic (Chanderbali et al., 2001) to Recent.

\section{ANGIOSPERM GROUP 4}

Characteristics. Asymmetric base and convex left side. Entire and smooth margin. Brochidodromous secondary veins, uniformly curved. Simple intersecondary veins perpendicular to the middle vein, connecting with the secondary vein with a sinuous course. Have epidemial tertiary percurrent veins. 
M8 morphotype

(Figure 4H-H')

Morphotype example. HUQ-RMF 48.

Material. HUQ-RMF 48.

Description. Incomplete leaf impression. Size $3 \mathrm{~cm}$ long and $1 \mathrm{~cm}$ wide. General leaf shape slightly asymmetric, the left side being $8 \mathrm{~mm}$ wide and $4 \mathrm{~mm}$ on the right side. Entire and smooth margin. Asymmetric base and convex left side, while the right side is recurrent. Apex not preserved. Three primary veins, leaving the base, one of them runs through $25 \%$ of the blade, the second through $75 \%$ and the third acts as a middle vein that runs completely through the blade and presents a sinuous course. Brochidodromous secondary veins, uniformly curved, with an angle of divergence of $46^{\circ}$, therefore narrowly acute; with a length of $1.4 \mathrm{~cm}$, the distance between veins of 4-11 mm, increasing towards the apex. Simple intersecondary veins perpendicular to the middle vein, connecting with the secondary vein with a sinuous course. Have epidemial tertiary percurrent veins.

Discussion. One specimen was identified with the characteristics of the family Fabaceae Lindley, 1836, characterized by its asymmetric and convex base. Full and smooth margin. Brochidodromal secondary nerves, uniformly curved, simple intersecond veins perpendicular to the middle vein are connected to the secondary vein in a sinuous course. In the genus Calliandra Bentham, 1840, the leaves are stipulate and bipinnate with opposite leaflets. None has extrafloral nectaries. Overall, in this genus leaf shape is ovoid (though occasionally distally truncated). The venation pattern in all species of the series is brochidodromous (Macqueen \& Hernández, 1997). The single primary vein is stout in $C$. palmeri and moderate for the other species and is always straight. Secondary veins are slightly asymmetric, arranged alternately towards the tip. The secondary veins are moderate in size and looped. All the above characteristics of Calliandra are found in our specimen.

Systematic affinity. Calliandra Bentham, 1840.

Geographic occurrence. Holguin Village, La Victoria Municipality, Cauca River Valley.

Age. Chibanian, Pleistocene.

Stratigraphic occurrence. The genus Calliandra ranges from Paleogene (Calvillo-Canadell \& Cevallos-Ferriz, 2005) to Recent.

\section{M9 morphotype \\ (Figure 4I-I')}

Morphotype example. HUQ-RMF 78.

Material. HUQ-RMF 78.

Description. Fragment of leaf impression, $3.5 \mathrm{~cm}$ long and $1.3 \mathrm{~cm}$ wide. Ovate and symmetrical shape. Base apparently corded. Seemingly entire margin. Petiole $<1 \mathrm{~cm}$ long, apparently with the presence of a partially preserved pulvinule. Primary veins apparently straight to curved, well-marked. Brochidodromous secondary veins, form a series of arches. Third and fourth order veins are not very visible. Furthermore, it is inferred as a possibly bilobed laminar shape.

Discussion. One specimen was identified for this morphotype, where the characteristics could correspond to the family Fabaceae and genus Bauhinia Linnaeus, 1753. These family and genus present acrodrome venation 2 with 3-5 primary veins by lobe or leaflet. All these first-order veins thin out as they approach the margin and may branch out to reach it. When a bifurcation appears, it can curve and join a branch of the overlying primary vein (Fortunato, 1986). It has nectarines in some species.

Systematic affinity. Bauhinia sp.

Geographic occurrence. Veraguas farm, Montenegro Municipality, La Vieja River Valley.

Age. Pleistocene.

Stratigraphic occurrence. The genus Bauhinia ranges from Paleogene (Wang et al., 2014) to Recent.

$$
\begin{aligned}
& \text { M10 morphotype } \\
& \text { (Figure 4J-J') }
\end{aligned}
$$

Morphotype example. HUQ-RMF 43.

Material. HUQ-RMF 3, 10, 40, 43, 57.

Description. Leaf impressions. Size $3 \mathrm{~m}$ long by $2.8 \mathrm{~cm}$ wide. Elliptical and symmetrical shape. Convex base. Apparently toothed margin. Pulvinate/nectarine petiole $4 \mathrm{~mm}$ long and 2 $\mathrm{mm}$ wide. Pinnate venation. Massive straight primary vein. Secondary veins brochidodromous, with an acute angle of divergence $32^{\circ}$, uniformly arched; with a length of $3 \mathrm{~cm}$ at the base, distance between them of 3-9 $\mathrm{mm}$, increasing slightly towards the apex. Two intersecondary veins with curved course connecting with a secondary vein, being perpendicular to the midrib. An intersectional vein greater than $50 \%$, respect to the other. Percurrent tertiary veins, with a curved course and a vein parallel to the intercostal tertiary with a sinuous course. Quaternary venation well marked, forming areoles. Quadrangular to rectangular areolas. Venules present poorly differentiated.

Discussion. Five specimens were identified for this morphotype, where the characteristics could correspond to the family Fabaceae and genus Inga Miller, 1754 that is characterized by its asymmetric and convex base, full and smooth margin. The genus Inga is known for the uniformity of its morphology. They all have pinnate venation. Secondary veins brochidodromous, percurrent tertiary veins. Present paripinnate leaves (compound leaves ending in a pair of leaflets) with characteristic leaf nectarines found between each pair of leaflets along the leaf rachis (Soto et al., 2012). In these specimens there are leaves that probably have paleoherbivory, identified in the specimen HUQ-RMF 43 with three marks of circles probably belonging to the herbivory process and the specimen HUQ-RMF 57 shows several galleries of ichnofossils, with random distribution, wide, ovate, smooth, and shiny, flat base and $0.1 \mathrm{~cm}$ wall thickness and $0.7 \mathrm{~cm}$ deep (Koptur, 1984). 
Systematic affinity: Inga sp.

Geographic occurrence: Holguin Village, La Victoria municipality, Cauca River Valley.

Age: Chibanian, Pleistocene.

Stratigraphic occurrence: The genus Inga ranges from Miocene (Richardson et al., 2001) to Recent.

\section{ANGIOSPERM GROUP 5}

Characteristics. Acrodroma venation and curved that runs through the lamina from the base to the apex). Tertiary venation opposite percurrent shape with a sinuous one, the secondary veins can be basal.

\section{M11 morphotype}

(Figure 4K-K')

Morphotype example. HUQ-RMF 12.

Material. HUQ-RMF 12, 16, 18, 31.

Description. Incomplete leaf impression, $1.7 \mathrm{~cm}$ long and 1.8 $\mathrm{cm}$ wide, base and apex not preserved. The margin cannot be set. However, the fragment has second-order venation, probably acrodroma arched, deep, which generates a bulbous appearance to the leaf blade, with a length of $1.8 \mathrm{~cm}$, and with a distance between them of 0.1 to $0.3 \mathrm{~mm}$. Tertiary veins are arranged obliquely in relation to the middle vein, opposite percurrent shape with a sinuous course, with a distance between it of $0.09 \mathrm{~mm}$.

Discussion. Four specimens were identified for this morphotype, belonging to the family Melastomataceae Jussieu, 1789 by the type of acrodroma venation. The characteristics could correspond to the genera Miconia Ruiz \& Pavón, 1794 or Climedia Rafarin, 1877. These genera have acrodromous venation and a curve that crosses the lamina from the base to the apex. Tertiary vein arranged obliquely in relation to the middle vein, percurrent shape opposite to another sinuous one, the secondary veins can be basal (they arise just where the lamina begins), or suprabasal (they arise on the base of the lamina) (Mendoza \& Ramírez, 2006). Due to preservation was not possible to specify to which of these two genera our specimens belong.

Systematic affinity. Miconia?/Climedia?.

Geographic occurrence. Holguin Village, La Victoria municipality, Cauca River Valley.

Age. Chibanian, Pleistocene.

Stratigraphic occurrence. The genera range from Paleogene (Goldenberg et al., 2008) to Recent.

\section{ANGIOSPERM GROUP 6}

Characteristics. Primary veins three, massive and curved. Alternate secondary veins, anastomosing near the margin forming arches that finally run through the entire leaf blade. Reticulated tertiary veins.

M12 morphotype

(Figure 4L-L')
Morphotype example. HUQ-RMF 74.

Material. HUQ-RMF 74.

Description. Incomplete leaf impression. Sheet fragment size $8.5 \mathrm{~cm}$ wide and $4 \mathrm{~cm}$ long. Entire margin. Primary veins three, massive and curved. Alternate secondary veins, 5 to $6 \mathrm{~cm}$ long, bifurcating at $3.5-4 \mathrm{~cm}$ towards the apex, anastomosing near the margin forming arches that finally run through the entire leaf blade. Reticulated tertiary veins. Quaternary veins partially marked.

Discussion. One specimen was identified for this morphotype, of which the characteristics could correspond to the family Araceae Jussieu, 1789. Araceae has alternate leaves, often all basal, simple and whole, with significant parallelinervial, pinnate or palmate veins (Engler \& Krause, 1914). In addition, this morphotype presents leaves that are stipulate and bipinnate with opposite leaflets. The combination of characters of the leaves has a low level of detail, however, it highlights the detail of short transverse veins and irregular pattern.

Systematic affinity. Araceae.

Geographic occurrence. Veraguas farm, Montenegro Municipality, La Vieja River Valley.

Age. Pleistocene.

Stratigraphic occurrence. The family Araceae ranges from Cretaceous (Nauheimer et al., 2012) to Recent.

\section{ANGIOSPERM GROUP 7}

Characteristics. Main venation parallel, of two or more size classes, the veins joining successively from the outside at the apex and forming a fimbrial vein, transverse veinlets.

\section{M13 morphotype (Figure 4M-M')}

Morphotype example. HUQ-RMF 66.

Material: HUQ-RMF 66, 67, 69, 71, 72, 73, 75.

Description. Several fragments of leaf impressions, their dimensions are $2.5 \mathrm{~cm}$ long and $0.5 \mathrm{~cm}$ wide, with approximately 20 parallel veins. One specimen belongs to a horsetail stem, its dimensions $0.7 \mathrm{~cm}$ and $0.3 \mathrm{~cm}$ wide, with approximately 13 parallel striations throughout the sample.

Discussion. Seven specimens were identified for this morphotype, where the characteristics could correspond to the families Cyperaceae Jussieu, 1789 or Poaceae Barnhart, 1895. These families had an entire margin or minimally serrated, with parallel venation, linear, flattened, and thin. In addition, the specimens have approximately 20 parallel veins. Due to preservation was not possible to specify to which of these two genera our leaves specimens belong. Seeds of Cyperaceae were identified from the material recovered from the sediment's preparation.

Systematic affinity. Cyperaceae?/Poaceae?

Geographic occurrence. Veraguas farm, Montenegro Municipality, La Vieja River Valley.

Age. Pleistocene.

Stratigraphic occurrence. Cyperaceae and Poaceae families ranges from Cretaceous (Janssen \& Bremer, 2004; Besnard et al., 2009) to Recent. 
Seeds

\section{ANGIOSPERM GROUP 8}

Characteristics. Form seed is a type of achene. Obovoidaloblong shape, slightly curved, laterally with a pronounced crest. Ornamentation structure (papus?) in the basal part of the achene, furthermore circular to hexagonal.

\section{M1 morphotype}

(Figure 5A)

\section{Morphotype example. HUQ-RMF 91.}

Material. Slide HUQ-RMF 91.

Description. Seminal body with dimensions $\sim 190.2 \mu \mathrm{m}$ long and $\sim 87.9 \mu \mathrm{m}$ wide. Type to of achene. Obovoidaloblong shape, slightly curved, laterally with a pronounced crest. Truncated base and with traces of a possible accessory. Apex incomplete, apical ends with acute appearance. Ornamentation of the ribbed surface with the presence of circular to hexagonal cell bodies and scattered remnants of the seminal cover.

Discussion. Two complete seminal bodies were identified for this morphotype, of which the characteristics could correspond to the family Asteraceae Berchtold \& J. Presl, 1820. These specimens are different from the other morphotypes by distinctive characteristics, as the narrowly oblong to oblanceolate contour typical of Asteraceae (Ozcan, 2017). The principal character can be associated with the presence of an ornamental structure (papus?) in the basal part of the achene (Hussein \& Eldemerdash, 2017).

Systematic affinity. Asteraceae.

Geographic occurrence. Veraguas farm, Montenegro Municipality, La Vieja River Valley.

Age. Pleistocene.

Stratigraphic occurrence. The family Asteraceae ranges from Eocene (Kim et al., 2005) to Recent.

\section{ANGIOSPERM GROUP 9}

Characteristics. Form of achene is trigone, apiculate truncated apex. Ornamentation of the surface with a papulose.

\section{M2 morphotype}

(Figure 5B)

Morphotype example. HUQ-RMF 91.

Material. Slide HUQ-RMF 91.

Description. Seeds with dimensions $\sim 132.1 \mu \mathrm{m}$ long and $\sim 35.8 \mu \mathrm{m}$ wide. Type achene trigone, in longitudinal view with three concave faces and base with a slight constriction, forming a small stipe. Apiculate truncated apex. Elliptical elongated shape. Ornamentation of the surface with a papulose appearance.

Discussion. Fifteen specimen of complete bodies and one seminal body disjointed. The characteristics of this morphotype could correspond to the family Cyperaceae Juss, 1789, genus Cyperus Linnaeus, 1753. Of this genus a diagnostic characteristic is the type of ornamentation on the surface of the achene. These seminal bodies are characterized mainly by their trigonal shape (generally it can vary), however the SEM analysis allowed to distinguish cell bodies that generally accompany this genus and the presence of a stipet in the apical part (Hefler \& Longhi-Wagner, 2008; Martinetto, 2014).

Systematic affinity. Cyperus sp.

Geographic occurrence. Veraguas farm, Montenegro municipality, La Vieja River Valley.

Age. Pleistocene.

Stratigraphic occurrence. The genus Cyperus ranges from Paleogene (Janssen \& Bremer, 2004) to Recent.

M3 morphotype

(Figure 5C)

Morphotype example. HUQ-RMF 91.

Material. Slide HUQ-RMF 91.

Description. Seeds with dimensions $\sim 122.1 \mu \mathrm{m}$ long and $\sim$ $80.2 \mu \mathrm{m}$ wide. Achene-type seminal body, in frontal view with trigonal contour features. Ellipsoidal to pear-shaped. Globose base with several longitudinally marked nerves towards the peak of the utricle. Deep grooves towards the middle part of the fruit. Smooth-looking surface ornamentation, without the presence of silica parts or any other accessory.

Discussion. A single full seminal body was identified belonging to this morphotype, where the characteristics could correspond to the family Cyperaceae, genus Carex Linnaeus, 1753. This genus is distinctive by the presence of what may be an utricle (achene), in addition the achenes studied included the types of elliptical to obovate contours, characteristics that have not changed with the current descriptions of the genus (Jiménez-Mejías \& Martinetto, 2013).

Systematic affinity. Carex sp.

Geographic occurrence. Veraguas farm, Montenegro municipality, La Vieja River Valley.

Age. Pleistocene.

Stratigraphic occurrence. The genus Carex ranges from Paleogene (Janssen \& Bremer, 2004) to Recent.

\section{INDETERMINATE GROUP}

M4 morphotype

(Figure 5D)

Morphotype example. HUQ-RMF 91.

Material: Slide HUQ-RMF 91.

Description. Dimensions $\sim 185.6 \mu \mathrm{m}$ long and $\sim 56.7 \mu \mathrm{m}$ wide. Seminal body, apparently trigone, compressed lateral cavities, and pronounced ridges. Ovoid to ellipsoid shape. Truncated base and truncated apical ends. Ornamentation of the surface possibly smooth.

Discussion. Ten seminal bodies. Slightly narrow margins. Specimens are difficult to identify to any taxon level, without additional information. 


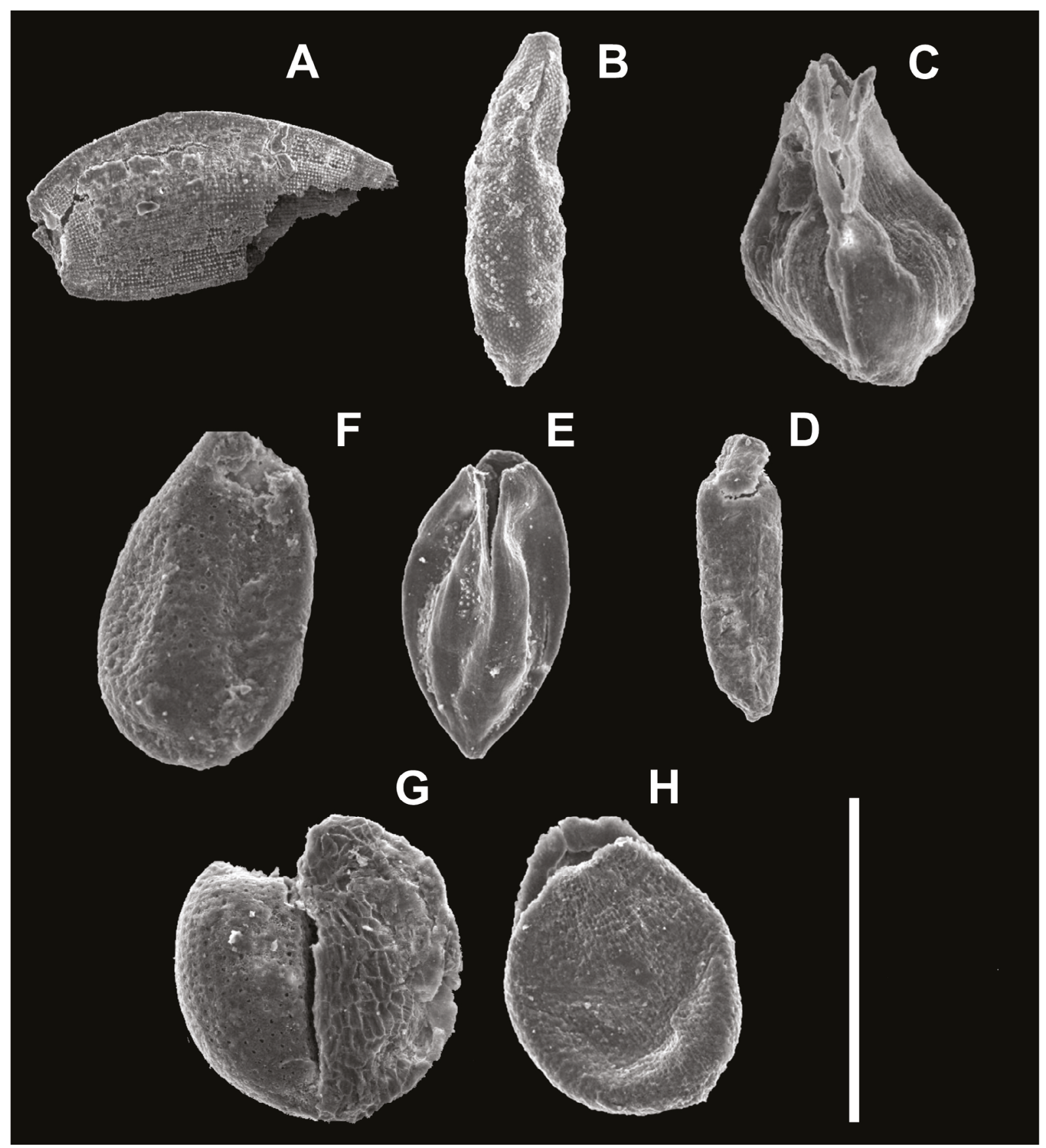

Figure 5. Scanning electron microscopy photographs of the seed morphotypes. Family Asteraceae (A); family Cyperaceae: Cyperus sp. (B) Carex sp. (C); taxonomically indeterminate specimens (D-H). All specimens are from the Veraguas outcrop, Montenegro-Q. Scale bar $=0.1 \mathrm{~mm}$.

Geographic occurrence. Veraguas farm, Montenegro Municipality, La Vieja River Valley.

Age. Pleistocene.

\section{M5 morphotype \\ (Figure 5E)}

Morphotype example. HUQ-RMF 91.

Material. Slide HUQ-RMF 91.

Description. Dimensions $\sim 58.7 \mu \mathrm{m}$ long and $\sim 19.2 \mu \mathrm{m}$ wide. Elongated elliptical shape, with a thin contour, in the central portion a fine crest that runs longitudinally through the seminal body and ends in the apical part with a lateral direction or ending in depression. Slightly globose base with an opening. Ornamentation of the irregular seminal surface. Discussion. Eleven seminal whole and fragmented bodies. Morphological characters of the specimen surface little detailed. Specimens appear to have been slightly elliptical and thin, the ornamentation patterns on the surface are not very distinctive, it is not possible to investigate the relationships beyond the superficial similarity with other specimens.

Geographic occurrence. Veraguas farm, Montenegro municipality, La Vieja River Valley.

Age. Pleistocene. 
M6 morphotype

(Figure 5F)

Morphotype example. HUQ-RMF 91.

Material. Slide HUQ-RMF 91.

Description. Dimensions $\sim 122.2 \mu \mathrm{m}$ and $\sim 39.1 \mu \mathrm{m}$ wide. Obovoid shape. In the lateral portions, it presents concavities.

Globose and rounded base. Apex with a pore of entire margins. Ornamentation of the punctate and irregular seminal surface.

Discussion. Eleven seminal bodies. Lack of diagnostic features. The distinguishing characteristics are not sufficient to identify relationships for any taxon, poor preservation.

Geographic occurrence. Veraguas farm, Montenegro municipality, La Vieja River Valley.

Age. Pleistocene.

\section{M7 morphotype}

(Figure 5G)

Morphotype example. HUQ-RMF 91.

Material. HUQ-RMF 91.

Description. Dimensions $\sim 123.4 \mu \mathrm{m}$ long and $\sim 74.2 \mu \mathrm{m}$ wide. Orbicular shape, circular ovoid in outline, with the presence of a groove on the seminal surface, which protrudes from the apex and runs laterally. At the central part of the base, the lateral end has a low crest. Ornamentation of the seminal surface varies in two types of ornamentation, pinpoint to reticulated-rough.

Discussion. Twenty-eight seminal complete and fragmented bodies. The ornamentation details are complex and vary on the surface of the specimen. The specimens may probably present a distinctive dispersion characteristic, due to the types of variation in its ornamentation it is necessary to evaluate more characteristics.

Geographic occurrence. Veraguas farm, Montenegro municipality, La Vieja River Valley.

Age. Pleistocene.

\section{M8 morphotype \\ (Figure 5H)}

\section{Morphotype example. HUQ-RMF 91.}

Material. Slide HUQ-RMF 91.

Description. Dimensions $\sim 101.6 \mu \mathrm{m}$ long and $\sim 97.2 \mu \mathrm{m}$ wide. Obovoid shape. Rounded base, with a slightly globose central prominence and flat apical opening, open longitudinally, ventrally concave towards the center of the base and whole lateral ends. Ornamentation of the surface is longitudinal square angular, apparently uniform.

Discussion. Forty-one seminal bodies, some fragmented. Some details of surface ornamentation are preserved. However, there are not sufficient characteristics for the evaluation of possible taxonomic relationships. This is the most abundant fruit morphotype recovered in the Veraguas section, Montenegro, Quindío. The remains are properly preserved, however, to help establish taxonomic relationships, more characteristics need to be evaluated.

Geographic occurrence. Veraguas farm, Montenegro municipality, La Vieja River Valley.

Age. Pleistocene.

Table 1. Leaf impressions and microseeds recovered from the Zarzal Formation.

\begin{tabular}{|c|c|c|c|c|c|}
\hline & Class & Family & Genus & Holguín & Veraguas \\
\hline Pteridophyta & Polypodiopsida & Thelypteridaceae & Thelypteris (Leaf) & 3 & \\
\hline \multirow[t]{15}{*}{ ANGIOSPERMAE } & \multirow[t]{6}{*}{ Liliopsida } & Family indet. (Leaf) & & & 2 \\
\hline & & Araceae (Leaf) & & 1 & \\
\hline & & Poaceae?/Cyperaceae? (Leaf) & & & 7 \\
\hline & & Asteraceae (Seeds) & & & 1 \\
\hline & & \multirow{2}{*}{ Cypereraceae } & Carex sp. (Seeds) & & 1 \\
\hline & & & Cyperus sp. (Seeds) & & 15 \\
\hline & \multirow[t]{9}{*}{ Magnoliopsida } & Family indet. (Leaf) & & 14 & \\
\hline & & \multirow{4}{*}{ Lauraceae } & Gen. indet. (Leaf) & 9 & \\
\hline & & & Nectandra sp. 1 (Leaf) & 8 & \\
\hline & & & Nectandra sp. 2 (Leaf) & 1 & \\
\hline & & & Ocotea sp. (Leaf) & 1 & \\
\hline & & \multirow{3}{*}{ Fabaceae } & Calliandra sp. (Leaf) & 1 & \\
\hline & & & Inga sp. (Leaf) & 5 & \\
\hline & & & Bauhinia sp. (Leaf) & & 1 \\
\hline & & Melastomataceae (Leaf) & Miconia?/ Climedia? (Leaf) & 4 & \\
\hline \multirow[t]{2}{*}{$\begin{array}{l}\text { Indeterminated } \\
\text { (Leaves - Seeds) }\end{array}$} & & & & 38 (Leaves) & $\begin{array}{l}4 \text { (Leaves) } \\
102 \text { (Seeds) }\end{array}$ \\
\hline & & & Total specimens $\rightarrow$ & 86 leaf impressions & $\begin{array}{l}14 \text { leaf impressions - } \\
119 \text { Seeds }\end{array}$ \\
\hline
\end{tabular}




\section{SYSTEMATICS DISCUSSION}

Many recovered fossil impression leaves were obtained from Holguín Village, La Victoria Municipality, VC, West of the SSB. A total of 72 specimens were identified and 14 undetermined (Table 1). Most of the specimens correspond to leaf fragments with veins to the $3 \mathrm{rd}, 4$ th, or 5 th order, in addition to a small group of complete leaves with 5 th order veins, areoles, and venules. Seeds were not recovered from this locality.

From La Vieja River Valley (Veraguas farm, Montenegro-Q), East of the SSB, fourteen leaf impressions were recovered and distributed in three angiosperm families: Poaceae?/ Cyperaceae?, Araceae and Fabaceae. On leaves, venations are preserved only up to the 2nd order, which made their taxonomic determination difficult. Seeds were also recovered from the Veraguas outcrop, analyzing a total of 119 specimens for morphologically classification (Table 1). The exomorphological diversity has resulted in the recognition of eight seminal morphotypes, their taxonomic affinities were established involving two families and two genera. Five morphotypes remain unidentified. The bulk material corresponds to wellpreserved specimens. However, several seeds were not be determined because of the few observable characteristics, but some features suggest that these belong to different taxa.

\section{PALEOENVIRONMENT AND PALEOECOLOGY}

Based on the paleobotanical remains, two different plant assemblages are recognized in the Plio-Pleistocene lacustrine deposits of the Zarzal Formation. The Plant Association I in the Rio Cauca Basin (Holguin) to the west of the SSB, with eight morphotypes, could correspond to a Sub-Andean forest based in the presence of families as Lauraceae, Fabaceae, and Melastomataceae. Lauraceae and Fabaceae have arboreal/shrubby habits as evidenced by the net abundance of veined angiosperm leaves with venation up to fifth order (Vásquez et al., 2005; Wing et al., 2009; Idárraga-Piedrahíta et al., 2011). The fossil remains recovered from this basin correspond only to leaf impressions, but due to their excellent state of preservation with abundant complete leaves, the association can be considered as autochthonous to parautochthonous, wind transport of leaves may had been expressive. The Plant Association II in La Vieja River Basin (Veraguas) to the east of the SSB, with three leaf morphotypes and eight seed morphotypes of Angiospermae affinity, is dominated by morphotypes typical of swamps, where fossil leaves of the Cyperaceae?/Poaceae? were identified, these plants are characteristics of lake margins and adjacent areas. Several seeds belong to the Cyperaceae and are represented by two genera: Carex and Cyperus, but also specimens of Asteraceae were identified (Figure 4). Nowadays, Cyperaceae is characteristic of wet environments as swamp areas (Strömberg, 2011; Spalink et al., 2016), and due to their well-preserved seeds in the Veraguas locality, is inferred that may correspond to areas of flooded environment and grass-like vegetation. The presence of Cyperaceae seeds in this plant association, support the identification of some plant groups through leaves. Although their taxonomic affinities cannot be, in some cases, accurate for some genus or species, the distinctive morphological characters are congruent with some living members and the available fossil records. By the preservational characteristics of plant remains and the presence of microseeds, the Plant Association II is considered to be parautochthonous indicating that, although it is representing vegetation growing very close to the lake, also the very fragmented leaf remains were consequence of transport probably by water stream before the final deposition of the sediments (Mancuso, 2009; Serrano Brañas \& Reyes Luna, 2014).

According to Suter et al. (2008), two different lacustrine deposits can be identified for the Zarzal Formation, one to the east and another to the west of Serranía Santa Bárbara (SSB) mountain range. To the west SSB, the Zarzal Formation is well dated as Chibanian (Middle Pleistocene by Jaramillo et al., 2017). Despite of a lack of age dating east damn, Suter et al., (2008) considered the lacustrine deposits as products of independent events, both occurred during the Pleistocene, but a more precise radiometric dating is missed for the east SSB deposit. The inferred older lake to the east of SSB was small-sized and contained several terrigenous contributions. The lake located to the west of SSB was larger and probably overflowed to the mountain ranges foothills.

The differences between the plant associations of Veraguas and Holguin localities could be a consequence of the environmental conditions of each deposit. Following the concepts of Mancuso (2009) and Serrano Brañas \& Reyes Luna (2014), fragmented fossil plants and abundant seeds in Veraguas, interpreted as parautocthonous, could be a consequence of debris transport by water to the lake, this can be corroborated by the contribution of terrigenous materials to the first lacustrine stage. The abundance of SubAndean forest elements as leaves of Lauraceae, Fabaceae and Melastomataceae, with good preservation and considered as authoctonous despite be typical components of higher elevations, could be explained because of dimensions of the last lacustrine stage and the possibility that the dam, flooded over the gallery forest.

\section{CONCLUSIONS}

The study of the areas of Veraguas and Holguín allowed the identification of thirteen morphotypes of foliar impressions grouped in six botanical families of Angiosperms: Poaceae?/ Cyperaceae?, Araceae, Melastomataceae, Fabaceae, and Lauraceae; and a family of Pteridophyta: Thelypteridaceae. On the other hand, only in the area of Veraguas very wellpreserved silicified seeds were identified, grouped in eight morphotypes, belonging to the families Cyperaceae and Araceae. The Zarzal Formation paleolakes flooded a complex geologically area that was surrounded by distinct geographic structures, this led to the accumulation and lithification of sediments with diachronous different origins, as corroborated 
herein with fossil plants. The identified plant specimens, their preservation, and host sediments led to characterize two different paleoenvironments to the west and to the east of the Serranía Santa Barbara mountain range. A Sub-Andean gallery forest is inferred to the Holguin locality (W of the SSB) where well-preserved arboreal/shrubby plants dominated. The Veraguas locality (E of the SSB) with a good record of seeds and weakly preserved leaves typical of grass-like vegetation, display characteristic of a swamped floodplain.

\section{ACKNOWLEDGEMENTS}

The authors would like to thank R. Mendes Melo from the Laboratory of Applied Micropaleontology of the Federal University of Pernambuco, for the SEM photographs. We are also grateful to G.D. Gomez for the field accompanying and presentation of Veraguas outcrop.

\section{REFERENCES}

Batsch, A.J.G.C. 1802. Tabula Affinitatum Regni Vegetabilis, p. 121. Bedoya, E.L. \& Giraldo, D.F. 2009. Estratigrafia detallada de la Formación La Paila en la sección Buga-la habana (municipio de Buga-valle del Cauca). Programa de Geología, Facultad de Ciencias Exactas y Naturales, Universidad de Caldas, B.S. thesis, $138 \mathrm{p}$.

Besnard, G.; Muasya, A.M.; Russier, F.; Roalson, E.H.; Salamin, N. \& Christin, P.-A. 2009. Phylogenomics of C4 photosynthesis in sedges (Cyperaceae): multiple appearances and genetic convergence. Molecular Biology and Evolution, 26:1909-1919. doi:10.1093/molbev/msp103

Botero, V.L. 2015. Estudio morfológico de helechos hallados en la Formación Mesa (Plioceno) entre los Municipios de la Doraday Norcasia, al oriente de Caldas. Programa de Geología, Facultad de Ciencias Exactas y Naturales, Universidad de Caldas, Trabajos de grado de pregrado.

Brongniart, A.T. 1843. Enumeration des Generes de Plantes cultives au Museum d'Histoire Naturelle de Paris. Paris, Fortin, Masson et $\mathrm{Cie}, 136 \mathrm{p}$.

Calvillo-Canadell, L. \& Cevallos-Ferriz, S.R.S. 2005. Diverse assemblage of Eocene and Oligocene leguminosae from Mexico. International Journal of Plant Sciences, 166:671-692. doi:10.1086/430096

Chanderbali, A.S.; Van der Werff, H. \& Renner, S.S. 2001. Phylogeny and historical biogeography of Lauraceae: evidence from the chloroplast and nuclear genomes. Annals of the Missouri Botanical Garden, 88:104-134. doi:10.2307/2666133

Collinson, M.E. 2001. Cenozoic ferns and their distribution. Brittonia, 53:173-235. doi:10.1007/BF02812700

Ellis, B.; Douglas, C.D.; Hickey, L.J.; Johnson, K.R.; Mitchell. J.D.; Wilf, P. \& Wing, S.L. 2009. Manual of leaf architecture. Cornell University Press in association with the New York Botanical Garden, 200 p. doi:10.1600/036364409790139682

Engler, A. \& Krause, K. 1914. Araceae. Notizblatt des Königl. Botanischen Gartens und Museums zu Berlin-Dahlem (Post Steglitz), sowie der botanischen Zentralstelle fur die deutschen Kolonien, 113-117.

Fortunato, R.H. 1986. Revision del género Bauhinia (Cercideae, Caesalpinioidea, Fabaceae) para la Argentina. Darwiniana, 27:527-557.
Ghimire, B.; Suh, G.U.; Lee, C.H.; Heo, K. \& Jeong, M.J. 2018. Cypsela morphology of Cirsium species (Asteraceae) and its taxonomic implications. Flora, 249:40-52. doi:10.1016/j. flora.2018.09.002

Goldenberg, R.; Penneys, D.S.; Almeda, F.; Judd, W.S.; \& Michelangeli, F.A. 2008. Phylogeny of Miconia (Melastomataceae): patterns of stamen diversification in a megadiverse neotropical genus. International Journal of Plant Sciences, 169:963-979. doi:10.1086/589697

Gomes-Bezerra, K.M.; Soares-Silva, L.H. \& Gomes, S.M. 2011. Arquitectura foliar de las Lauraceae del Distrito Federal, Brasil, y nuevos patrones de venación propuestos. Gayana, Botánica, 68:1-15. doi:10.4067/S0717-66432011000100001

Hefler, S.M. \& Longhi-Wagner, H.M. 2008. Análise da morfologia do fruto em espécies de Cyperus L. subg. Cyperus-Cyperaceae. Acta Botanica Brasilica, 22:637-651. doi:10.1590/S010233062008000300005

Hooghiemstra, H. \& Cleef, A.M. 1995. Pleistocene climatic change and environmental and generic dynamics in the north Andean montane forest and paramo. In: S.P. Churchill; H. Balslev; E. Forero \& J.L. Luteyn (eds.) Biodiversity and conservation of Neotropical montane forests, New York Botanical Garden, p. $35-49$.

Hussein, H.A. \& Eldemerdash, M.M. 2017. Comparative morphology and surface microsculpture of cypsela in some taxa of the Asteraceae and their taxonomic significance. Egyptian Journal of Botany, 56:409-422. doi:10.21608/ejbo.2017.1133

Idárraga-Piedrahíta, Á.; Ortiz, R. del C.; Callejas Posada, R. \& Merello, M. 2011. Flora de Antioquia. Catálogo de las plantas vasculares. Vol. II. Medellín, Universidad de Antioquia, 944 p.

Janssen, T. \& Bremer, K. 2004. The age of major monocot groups inferred from $800+$ rbcL sequences. Botanical Journal of the Linnean Society, 146:385-398. doi:10.1111/j.10958339.2004.00345.x

Jaramillo, D.; Vallejo, D.F.; Vélez, M.I.; Restrepo-Moreno, S.; PardoTrujillo, A.; Trejos-Tamayo, R.; Murcia, H.; Kyoungwon, M. \& Barbosa-Espitia, A. 2017. Middle Pleistocene palaeolimnology of a dammed tropical river: the Zarzal Formation, Cauca Valley, Colombia. Palaeogeography, Palaeoclimatology, Palaeoecology, 48:194-203. doi:10.1016/j.palaeo.2017.08.034

Jiménez-Mejías, P. \& Martinetto, E. 2013. Toward an accurate taxonomic interpretation of Carex fossil fruits (Cyperaceae): a case study in section Phacocystis in the Western Palearctic. American Journal of Botany, 100:1580-1603. doi:10.3732/ ajb. 1200629

Kim, K.J.; Choi, K.-S. \& Jansen, R.K. 2005. Two chloroplast DNA inversions originated simultaneously during the early evolution of the sunflower family (Asteraceae). Moleclular Biology and Evolution, 22:1783-1792. doi:10.1093/molbev/msi174

Koptur, S. 1984. Alternative defences against herbivores in Inga (Fabaceae: Mimosoideae) over an elevational gradient. Ecology, 66:1639-1650. doi:10.2307/1938026

Larridon, I.; Reynders, M.; Huygh, W.; Bauters, K.; Vrijdaghs, A.; Leroux, O.; Muasya, A.M.; Simpson, D.A. \& Goetghebeur, P. 2011. Taxonomic changes in C3 Cyperus (Cyperaceae) supported by molecular data, morphology, embryography, ontogeny and anatomy. Plant Ecology and Evolution, 144:327-356. doi:10.5091/plecevo.2011.653

López, M.; Moreno-Sanchez, M. \& Audemard, F.A. 2009. Deformación tectónica reciente en los pie de montes de las cordilleras central y occidental, Valle Del Cauca, Colombia. Boletín de Geología, 31:11-29. 
Macqueen, D.J. \& Hernández, H.M. 1997. A revision of Calliandra series racemosae (Leguminosae: Mimosoideae). Kew Bulletin, 52:1-50. doi: 10.2307/4117840

Mancuso, A.C. 2009. Taphonomic analysis in lacustrine environments: two different contexts for Triassic lake paleofloras from Western Gondwana (Argentina). Sedimentary Geology, 222:149-159. doi:10.1016/j.sedgeo.2009.05.017

Martinetto, E.; Bouvet, D.; Vassio, E.; Magni, P. \& Jiménez-Mejías, P. 2014. A new protocol for the collection and cataloguing of reference material for the study of fossil Cyperaceae fruits: the modern carpological collection. Review of Palaeobotany and Palynology, 201:56-74. doi:10.1016/j.revpalbo.2013.11.003

Mendoza, H. \& Ramírez, B. 2006. Guía ilustrada de géneros de Melastomataceae y Memecylaceae de Colombia. Bogotá, Instituto de Investigación de Recursos Biológicos Alexander von Humboldt, 288 p.

Moreno-Sanchez, M. 2008. Estratigrafía de la Formación La Paila, un potencial reservorio de hidrocarburos en la Cuenca Cauca-Patía. Manizales, Universidad de Caldas para la ANH. Informe Técnico.

Nauheimer, L.; Metzler, D. \& Renner, S.S. 2012. Global history of the ancient monocot family Araceae inferred with models accounting for past continental positions and previous ranges based on fossils. New Phytologist, 195:938-950. doi:10.1111/ j.1469-8137.2012.04220.x

Neuwerth, R. 2012. Lithostratigraphical and tectono-sedimentary study of the Plio-Pleistocene infill of the Interandean North Cauca Valley Basin. Faculté des Sciences, Université de Genève, Ph.D. thesis, $157 \mathrm{p}$.

Neuwerth, R.; Suter, F.; Guzman, C.A. \& Gorin, G.E. 2006. Softsediment deformation in a tectonically active area: the PlioPleistocene Zarzal Formation in the Cauca Valley (Western Colombia). Sedimentary Geology, 186:67-88. doi:10.1016/j. sedgeo.2005.10.009

Ozcan, M. 2017. Cypsela micromorphology and anatomy in Cirsium sect. Epitrachys (Asteraceae, Carduoideae) and its taxonomic implications. Nordic Journal of Botany, 35:653-668. doi:10.1111/njb.01670

Pérez-Cortéz, A.S.; Tillett, S. \& Escala, M. 2014. Estudio morfológico de la semilla de 51 especies del género Passiflora L. Acta Botánica Venezuélica, 25:67-96.

Pichi-Sermolli, R.E.G. 1970. A provisional catalogue of the family names of living pteridophytes. Webbia, 25:219-297.

Richardson, J.E.; Pennington, R.T.; Pennington, T.D. \& Hollingsworth, P.M. 2001. Rapid diversification of a species-rich genus of neotropical rain forest trees. Science, 293:2242-2245. doi:10.1126/science.1061421

Sanín, D.; Gómez-Cruz, A. de J. \& Moreno-Sánchez, M. 2016. Fossils of Thelypteris subg. Meniscium in Miocene deposits of the Cauca Valley, Colombia. Brittonia, 68:195-201. doi:10.1007/ s12228-015-9401-5

Savard, L.; Pi, P.; Strauss, S.H.; Chase, M.W.; Michaud, M. \& Bosquet, J. 1994. Chloroplast and nuclear gene sequences indicate late Pennsylvanian time for the last common ancestor of extant seed plants. PNAS, 91:5163-5167. doi:10.1073/pnas.91.11.5163

Serrano Brañas, C.I. \& Reyes Luna, P.C. 2014. Paleobotánica forense: una aproximación a la tafonomía de plantas. Boletín la Sociedad Geológica Mexicana, 66:25-39. doi:10.18268/ bsgm2014v66n1a3

Shalabi, L.F. \& Gazer, M.H. 2015. The taxonomic significance of achene micro-and macromorphology in Cyperus L. (Cyperaceae). Pakistan Journal of Botany, 47:2339-2346.
Smith, A.R. 1990. Thelypteridaceae. In: K.U. Kramer \& P.S. Green (eds.) Pteridophytes and gymnosperms, Springer, p. 263-272.

Smith, A.R. \& Cranfill, R.B.. 2002. Intrafamilial relationships of the thelypteroid ferns (Thelypteridaceae). American Fern Journal, 92:131-149. doi:10.1640/0002-8444(2002)092[0131:irottf]2 .0.co;2

Soltis, P.S. \& Soltis, D.E. 2004. The origin and diversification of angiosperms. American Journal of Botany, 91:1614-1626. doi:10.3732/ajb.91.10.1614

Soto, J.; Pacheco, D.; Zambrano, O. \& Ortega, J. 2012. Revisión florística del género Inga Miller (Leguminosae-Mimosoideae) en el Estado Zulia, Venezuela. Acta Botánica Venezuélica, 35:27-52.

Spalink, D.; Drew, B.T.; Pace, M.C.; Zaborsky, J.G.; Starr, J.R.; Cameron, K.M.; Givnish, T.J. \& Sytsma, K.J. 2016. Biogeography of the cosmopolitan sedges (Cyperaceae) and the area-richness correlation in plants. Journal of Biogeography, 43:1893-1904. doi:10.1111/jbi.12802

Strömberg, C.A.E. 2011. Evolution of grasses and grassland ecosystems. Annual Review of Earth and Planetary Sciences, 39:517-544. doi:10.1146/annurev-earth-040809-152402

Suter, F.; Neuwerth, R.; Gorin, G. \& Guzmán, C. 2008. (Plio-) Pleistocene alluvial-lacustrine basin infill evolution in a strike-slip active zone (Northern Andes, Western-Central Cordilleras, Colombia). Geologica Acta, 6:231-249. doi:10.1344/105.000000253

Trofimov, D.; Rudolph, B.; \& Rohwer, J.G. 2016. Phylogenetic study of the genus Nectandra (Lauraceae), and reinstatement of Damburneya. Taxon, 65:980-996. doi:10.12705/655.3

Van Der Hammen, T. 1958. Investigacion de algunos importantes yacimientos de Diatomita, Caolín y Arcillas de La Sabana de Bogotá. Boletín de Geología, 2:5-25.

Van Der Hammen, T. \& Hooghiemstra, H. 1997. Chronostratigraphy and correlation of the Pliocene and Quaternary of Colombia. Quaternary International, 40:81-91. doi:10.1016/s10406182(96)00064-x

Van der Werff, H. 2002. A synopsis of Ocotea (Lauraceae) in Central America and southern Mexico. Annals of the Missouri Botanical Garden, 89:429-451. doi:10.2307/3298602

Vásquez, R.M.; Rojas, R.G.; Monteagudo, A.M.; Meza, K.V.;Van der Werff, H.; Ortiz-Gentry, R. \& Catchpole, D. 2005. Flora vascular de la selva central del Perú: una aproximación de la composición florística de tres áreas naturales protegidas. Arnaldoa, 12:112-125.

Wang, Q.; Song, Z.; Chen, Y.; Shen, S.; \& Li, Z. 2014. Leaves and fruits of Bauhinia (Leguminosae, Caesalpinioideae, Cercideae) from the Oligocene Ningming Formation of Guangxi, South China and their biogeographic implications. BMC Evolutionary Biology, 14:88. doi:10.1186/1471-2148-14-88

Welsh, S.L.; Atwood, N.D.; Goodrich, S. \& Higgins, L.C. 1987. Division Magnoliophyta-Class Liliopsida. Great Basin Naturalist Memoirs, 9:11.

Wing, S.L.; Herrera, F.; Jaramillo, C.A.; Gómez-Navarro, C.; Wilf, P. \& Labandeira, C.C. 2009. Late Paleocene fossils from the Cerrejón Formation, Colombia, are the earliest record of Neotropical rainforest. PNAS, 106:18627-18632. doi:10.1073/ pnas.0905130106

Received in 27 September, 2020; accepted in 11 March, 2021. 